\title{
Islamic Identity and Transitional Democracy in Indonesia: Ideology, Public Sphere and Domination
}

\author{
Arif Rahman ${ }^{1}$, Zalik Nuryana ${ }^{2}$ \\ Universitas Ahmad Dahlan Yogyakarta, Indonesia ${ }^{1,2}$ \\ \{arif.rahman@pai.uad.ac.id $\left.{ }^{1}, \underline{z a l i k . n u r y a n a @ p a i . u a d . a c . i d ~}{ }^{2}\right\}$
}

\begin{abstract}
This research is to review the reformation agenda in Indonesia that has become the momentum of Islamic revival, especially in the public area. The religious symbols which mark the piety form in the general area started to rise after Soeharto's fall (New Order). During the democracy era, tradition provides an opportunity for Islamic movement to represent religious identity which often occurs through contestation and negotiation process among Islam, democracy system and political interest. The process dynamically always takes the public room as the area of Islamic identity shaping. It is review literature and performed through a qualitative method by using a sociological approach. The result of research is to find out democracy transition period, a new Islamic ideology movement which is finding a pattern and performing penetration to use the momentum. While in the contemporary era, the Islamic ideological movement tries to negotiate so that the existence of social role and status in the public area obtains its place.
\end{abstract}

Keywords: Islam, Ideology, Identity, public room.

\section{Introduction}

Indonesian is known with many predicates. Charlene Tan in the Islamic Education and Indoctrination termed it as" Islam with Smiling Face." According to his observation, all Islamic schools in Indonesia teach openness, pluralism and have promised future.[1].

It may be true because Indonesian Islam is different from Arabic Islam and Islam in Africa countries and Sahara Peninsula. Indonesian Islam has its special cultures and characteristics compared to Islam itself [2]. The Indonesian multicultural, religious and ethnical backgrounds have brought this country to have experience in its management. For example in Aceh region, Fikri in his research explained that the implementation of Islamic syariat or law in Aceh has not able to protect the multiculturalism in Aceh so that educational approach is required [3]. The syariat needs to be interpreted as the era change context and direction to the objective achievement [4].

The today and future's Islamic wave in Indonesia will be spread, in which the country provides the open role and room for the religious movement and ideology to take its action. The role of religion has shifted from private to public room area, in which the religion is believed should reflect all life aspects such as Islamic mobilization in the public area has touched various aspects. In the political field, "Islam 212" movement at the end of 2019 in 
Jakarta reflected how some Islamic movements took the momentum of Jakarta gubernatorial election. We all have known that what is called by Aksi Bela Islam or Islamic Defense Action is the opportunistic response of religious blasphemy [5]. The Islamic movement becomes the attention because it has an impact on many things. Arie Styaningrum explained that the other side of Islamic movement is the method shift in order to mobilize the mass with social media which is utilized to construct dakwah strategy and public morality politics which emphasize the code and ethics of the people's piety [6]. In this economy, the wriggle of syariat banks become the example of awareness quantitative graphical in muamalah and economy. In the educational field, Muhammadiyah presents with tajdid movement [7] becomes the front guard in the Islamic education field and followed by other Islamic organizations. This shift strengthens indication that the authorization in the Soeharto era has caused an attachment for Islam. Therefore, the reformation momentum in 1998 was marked by the fall of the New Order Regime (Soeharto), became the point of return of Islamic movements which experienced massive emergence.

Indonesia places itself as the third biggest democracy country with the biggest Moslem majority populations in the world. The success Indonesia experience during the democratic transition has pushed Islam and civil societies to become collectively important to create reformation and democracy effort. Although many parties have provided appreciation towards Indonesian Islam by considering the reality as the biggest pluralistic Moslem country, the plural potentials have taken the consensus towards the national disintegration anxiety. [8]. The country which "claims" as a religious country is inhabited by religious people who cannot ignore the Islamic fundamentalism and radicalism phenomenon. By using political, sociological approach, the dynamic of Islamic reflection in modern Indonesian world will be depicted in this writing, especially the identity of Islamic ideological movement in the public area during the democracy transition period in Indonesia. Ahyar explained that the political atmosphere and mass network could fasten the growth of radicalism

\section{Method}

This research used review literature and performed through a qualitative method by using a sociological approach. Previous research data was revealed and analyzed to see how the development of Islamic identity that later emerged in Indonesia as a democratic response or to clarify religious identity in Indonesia. The data which collected is analyzed descriptively, interpretatively, and comparatively.

\section{Result and discussion}

\subsection{Democracy Party: Piety and Ideology Contestation}

Modern Islam in Indonesia cannot be separated from the political arena. The relationship between Islam and politic have experienced its meeting since the beginning of Islam's development. In Indonesia, the wave of Islamic explosion obtains much attention from domestic or overseas [8]. Beside the entering history of Islam until the success of being majority religion, the modern era in Indonesia is known as the emergence of Islam variants that reflect many ideological movement types.

Two previous Islamic organizations which have been rooted in Indonesia such as Muhammadiyah and Nahdhatul Ulama have presented traditional people (NU) and modernist 
people (Muhammadiyah). Although they look to be opposition, both of them become modern strength which is called by Hefner as "multi-religious nationalism" commitment. Both of them are the main current of the Islamic movement which builds themselves as the Islamic social pillar in Indonesia[9]. The other Islam variants emerge after that by possessing various affiliations such as HTI (Hizbut Tahrir Indonesia), Salafi movement, Ikhwanul Muslimin which furthermore becomes PKS political party and Mujahidin committee and Islamic Defender Front (FPI). All of the movements are usually called "new Islamic movement."

During Indonesian reformation transition, the Islamic ideology movement enjoys the democracy liberalization system which emerges on the surface. However, some Islamic movement such as HTI values the democrazy system as kufr and toghut which are not in line with Islamic teaching. This movement wants a total change of administration system which is considered as un-Islamic. Until 2017 through Jokowi government, this movement is considered as social organization which against with Pancasila so that the emergency is officially forbidden. In 2010, Hiariej performed research towards five organizations which are considered as radical organizations. Furthermore, he explained that the research has provided a conclusion that in order to know themselves, the activists picture their group as the most original Moslems who have a lofty duty to implement the application of syariah in Indonesia [10].

The other Islamic movements also support the Islamic orientation which is implemented in Indonesia. They utter syariah through local regulation, authority, institution, and activism form on behalf of religion and God. On one hand, the legitimizing side is covered with piety normality seen as God's demand [11]. However, the truth value is often absolutely held by this group. Therefore, according to Syafi'I Ma'arif, the anger is when people act for the name of God and punish or even destroy different beliefs. So, according to him, intolerance attitudes encourage fundamentalism symptom which is for the last years experienced by them. [12].

\subsection{Islamic Fundamentalism; Hegemony and Conflict}

Fundamentalism phenomenon is possibly caused by some theories, such as first, Western modernity domination on Moslem countries in the contemporary world. Second, the suppression towards Islamic societies in Palestine, Syrian, and Afghanistan it causes Islamic brotherhood sympathy. The third is the country failure in order to implement social justice and rampant corruption. Karel provides a definition on the fundamentalism. According to him, this movement wants to revive the spirit and some practices which are considered as basic practice in Islam. For each fundamentalism movement, the opinion on general development in the modern world is very negative. The main objective of fundamentalism movement is isolation, holed up from this cruel world. It is strengthened with the thinking concerning the close doomsday. Following the emergence of elite feeling or a feeling on the selected group in each fundamentalist movement, the detestation towards people who have a different opinion also emerge [13].

In Indonesia, the fundamentalism ideological contestation in open room has signified the country absence in overcoming its role and function in the society. It's unique that the religious countries (the majority of Islam) tend to be in different line from the societies' interest. Collective corruption, poverty, waste pollution, Women Employees violence in Saudi Arabia and the low education quality become the evidence that the country doesn't show serious effort to overcome the problem. Meanwhile, more national humanity problems are increased. It is different from another opinion. Putra in his research concluded that Islamic 
fundamentalism has the potential to support the violent and non-violent actions in certain conditions [14].

The emergence of religion is aimed to disentangle the complexity and attract human to be separated from the materialistic and capitalist world. However, when the religion does not place on the sociology context of pluralistic Indonesia anymore, it is not surprising that the collision and friction occur when the religion has a loud voice but it closes its eyes with pluralism dynamic. It may be understood that sometimes the religious logic is not in line with humans' behaviors. However, if is believed in a wise manner, religion will be on the "peace symbol" for the believers. Faiqah in his research explained that the radicalism emergence should be balanced with moderate Islamic vision. It is Islam's image that upholds moderate, tolerant and right equality values [15]. Ahmad explained that fundamentalism does not always drive to radicalism. [16].

It is interesting that Geertz' comment that religion does not only play an integrative role and create social harmony in the society but also the role of separation to reflect the consideration between integrative and disintegrative power which exist on the social system.[17]. The religious conflict also completes the Geertz's thesis such as mosque combustion; church bombing, clergy (ulama) and religious leader are the conflicts which act on behalf of religion based on the understanding and belief difference. Even, the religion sometimes becomes the legitimizing to mobilize the mass to perform hegemony in the public area which threatens social life disintegration.

\subsection{Public Sphere and Islamic Identity}

Religious symbols through Quran text, clothes, lifestyle, religious figures, and social status are constructed into Islamic identity in social life on a global aspect. Even in the political area, Qur'an texts become the weapon to attract the electors' sympathy through religious leaders. Therefore, some Islamic ideology movements see the public room as ideological and political contestation arena. By paying attention to the Islamic phenomenon in the public area, it is interesting to see the reality of Islamic identity touches the modernism values such as democracy, tolerance and human rights. Although some Islamic ideology values provide a statement which is against the values concept, on the other hand, they perform negotiation with ideology commodification, social status, and modernism. [18]. It can be realized that ideology contestation experiences an adjustment both in the condition and situation. Iqbal in his research explained that Islamic fundamentalism is not anti-globalization movement, but for some parties, the participants and interpreter of globalization phenomenon. In this care, Iqbal discussed the case of Hizb-ut-Tahrir [19]. Meanwhile, Dahlan in his research explained the emergence of Islamic fundamentalism is the strong reaction towards the growth of Islam liberalism. [20].

Islamic identity, in this case, is constructed through social status legitimating. The existence of the Islamic movement should not ignore the modernism values on the group's interest. However, trying to offer a more Islamic administration system by radically change the concept and structure as pure Islamic teaching. They use democracy system to fill the room and try to take over the public arena through symbols, identity, and ideological activists.

\section{Conclusion}

Islamic ideology movement in public area has experienced a value shift in which Islamic identity moves dynamically to find its room for expressing their symbols and social status, 
especially in the post-Suharto's fall. During the democracy transition, new Islamic ideology movement finds a pattern and performs a penetration to use the momentum. While in the contemporary era, the Islamic ideological movement tries to negotiate the existence of social role and status in the public are to get its place.

\section{References}

[1] Charlene Tan, Islamic Education and Indoctrination: The Case in Indonesia. New York: Routledge, 2011.

[2] Z. Qodir, Radikalisme Agama di Indonesia. Yogyakarta: Pustaka Pelajar, 2014.

[3] M. Fikri, "Islam Persuasif dan Multikulturalisme di Aceh: Upaya Rekonstruksi Penerapan Syariat Islam Berbasis Pendidikan," Akad. J. Pemikir. Islam, vol. 20, no. 1, 2015.

[4] H. Susanto, "Democracy in Islam: comparative study of Muhammad Abid al-Jabiri and Abdolkarim Soroush's thoughts," Indones. J. Islam Muslim Soc., vol. 1, no. 2, p. 253, Dec. 2011.

[5] M. Woodward and A. Nurish, "Quo vadis FPI dalam aksi bela islam," Maarif, vol. 11, no. 2, 2016.

[6] A. S. Pemungkas and G. Octaviani, "Aksi Bela Islam dan Ruang Publik Muslim: Dari Representasi Daring ke Komunitas Luring,” J. Pemikir. Sosiol., vol. 4, no. 2, p. 65, Sep. 2017.

[7] Kuntowijoyo, Dinamika Internal Umat Islam Indonesia. Jakarta: LSIP, 1993.

[8] A. Rahman, Esai-esai Pendidikan Islam dalam Berbagai Perspektif. Yogyakarta: Diandra Creative, 2015.

[9] R. W. Hefner, Islamic Schools, Social Movements, and Democracy in Indonesia” in Robert W. Hefner (ed), Making Modern Muslims: The Politics of Islamic Education in Southeast Asia. USA: University of Hawai'i Press, 2014.

[10] E. Hiariej, "Aksi dan identitas kolektif gerakan Islam radikal di Indonesia," J. Ilmu Sos. dan Ilmu Polit., vol. 14, no. 2, pp. 131-168, 2010.

[11] A. Rahman, Multikulturalisme Pesantren: Menggagas Pendidikan Islam Pesantren Anti Radikal. Yogyakarta: Komojoyo Press, 2016.

[12] A. S. Maarif, "Masa Depan Islam di Indonesia," in Ilusi Negara Islam: Ekspansi Gerakan Islam Transnasional di Indonesia, A. Wahid, Ed. Jakarta: Wahid Institut, 2009 , p. 7.

[13] S. Kareel A, Beberapa Aspek Tentang Islam di Indonesia Abad ke-19. Jakarta: Bulan Bintang, 1984.

[14] I. E. Putra and Z. A. Sukabdi, "Can Islamic fundamentalism relate to nonviolent support? The role of certain conditions in moderating the effect of Islamic fundamentalism on supporting acts of terrorism.," Peace Confl. J. Peace Psychol., vol. 20, no. 4, pp. 583-589, 2014.

[15] N. Faiqah and T. Pransiska, "Radikalisme Islam vs Moderasi Islam: Upaya Membangun Wajah Islam Indonesia yang Damai," Al-Fikra, vol. 17, no. 1, pp. 33-60, 2018.

[16] S. Arifin and H. Bachtiar, "Deradikalisasi Ideologi Gerakan Islam Transnasional Radikal," Harmoni, vol. 12, no. 3, pp. 19-36, 2013.

[17] C. Geertz, Agama Jawa: Abangan, Santri, Priyayi dalam Kebudayaan Jawa. Jakarta: Komunitas Bambu, 2013. 
[18] N. Hasan, Between Global and The Local: Negotiating Islam and Democracy in Provincial Indonesia" in Gerry van Klinken and Ward Berenschot, In Search of Middle Indonesia: Miccle Classes in Provincial Town. London: Brill, 2014.

[19] A. M. Iqbal and Z. Zulkifli, "Islamic fundamentalism, nation- state and global citizenship: the case of Hizb ut-Tahrir," Indones. J. Islam Muslim Soc., vol. 6, no. 1, p. 35, Jun. 2016.

[20] F. Dahlan, "Fundamentalisme Agama: Antara Fenomena Dakwah dan Kekerasan Atas Nama Agama," J. Ilmu Dakwah, vol. 6, no. 2, p. 331, Nov. 2014. 